\title{
Factors limiting heterotrophic bacterial production in the southern Pacific Ocean
}

\author{
F. Van Wambeke ${ }^{1}$, S. Bonnet ${ }^{2}$, T. Moutin ${ }^{3}$, P. Raimbault ${ }^{3}$, G. Alarcón ${ }^{4}$, and C. Guieu ${ }^{2}$ \\ ${ }^{1}$ Laboratoire de Microbiologie, Géochimie et Ecologie Marines (LMGEM), CNRS, UMR 6117, Université de la \\ Méditerranée, Campus de Luminy - Case 901, 13288 Marseille cedex 9, France \\ ${ }^{2}$ CNRS, Laboratoire d'océanographie de Villefranche, 06230 Villefranche-sur-Mer, France; Université Pierre et Marie Curie \\ - Paris6, Laboratoire d'océanographie de Villefranche, 06230 Villefranche-sur-Mer, France \\ ${ }^{3}$ Laboratoire d'Océanographie et de Biogéochimie (LOB), CNRS, UMR 6535, Université de la Méditerranée, Campus de \\ Luminy - Case 901, 13288 Marseille cedex 9, France \\ ${ }^{4}$ Department of Oceanography \& Center for Oceanographic Research in the eastern South Pacific, University of Concepcion, \\ Casilia 160-C, Concepcion, Chile
}

Received: 26 September 2007 - Published in Biogeosciences Discuss.: 16 October 2007

Revised: 21 February 2008 - Accepted: 8 May 2008 - Published: 19 May 2008

\begin{abstract}
The role of potential factors limiting bacterial growth was investigated along vertical and longitudinal gradients across the South Eastern Pacific Gyre. The effects of glucose, nitrate, ammonium and phosphate additions on heterotrophic bacterial production (using leucine technique) were studied in parallel in unfiltered seawater samples incubated under natural daily irradiance. The enrichments realized on the subsurface showed three types of responses. From $141^{\circ} \mathrm{W}$ (Marquesas plateau) to approx $125^{\circ} \mathrm{W}$, bacteria were not bottom-up controlled, as confirmed by the huge potential of growth in non-enriched seawater (median of enhancement factor $\times 39$ in $24 \mathrm{~h})$. Within the Gyre $\left(125^{\circ} \mathrm{W}-\right.$ $\left.95^{\circ} \mathrm{W}\right)$, nitrogen alone stimulated leucine incorporation rates (median $\times 4.2$ ), but rapidly labile carbon (glucose) became a second limiting factor $($ median $\times 37)$ when the two elements were added. Finally from the border of the gyre to the Chilean upwelling $\left(95^{\circ} \mathrm{W}-73^{\circ} \mathrm{W}\right)$, labile carbon was the only factor stimulating heterotrophic bacterial production. Interaction between phytoplankton and heterotrophic bacterial communities and the direct versus indirect effect of iron and macronutrients on bacterial production were also investigated in four selected sites: two sites on the vicinity of the Marquesas plateau, the centre of the gyre and the Eastern border of the gyre. Both phytoplankton and heterotrophic bacteria were limited by availability of nitrogen within the gyre, but not by iron. Iron limited phytoplankton at Marquesas plateau and at the eastern border of the gyre. However
\end{abstract}

Correspondence to: F. Van Wambeke (france.van-wambeke@univmed.fr)
$48 \mathrm{~h}$ enrichment experiments were not sufficient to show any clear limitation of heterotrophic bacteria within Marquesas plateau and showed a limitation of these organisms by labile carbon in the eastern border of the Gyre.

\section{Introduction}

Heterotrophic bacteria generally meet their energy and elemental needs from utilisation of organic matter, which includes essential elements like C, N, P and Fe. However, in oligotrophic environments, elemental needs are sometimes not satisfied only by utilization of organic matter and heterotrophic bacteria can compete with phytoplankton for mineral nutrients like N, P or Fe (Kirchman, 1994; Tortell et al., 1999; Thingstad, 2000). To examine factors limiting heterotrophic bacterial growth, seawater samples are generally amended with various components (organic molecules, macro nutrients, iron), alone or in combination. After 24$48 \mathrm{~h}$, some bacterial parameters are examined, the main one primarily being bacterial production (either with thymidine or leucine technique). Different elements have been shown to stimulate bacterial production : phosphorus in the Atlantic Ocean (Sargasso Sea: Cotner et al., 1997, Gulf of Mexico: Pomeroy et al., 1995) and in the Mediterranean Sea (Eastern: Zohary and Robarts, 1998; Thingstad et al., 2005; Western: Van Wambeke et al., 2002), nitrogen in the South West Pacific Ocean (French Polynesia: Torréton et al., 2000), labile organic carbon in the Equatorial and Subarctic Pacific (Kirchman, 1990; Kirchman and Rich, 1997), iron in the Southern ocean (Pakulski et al., 1996, Tortell et al., 1996).

Published by Copernicus Publications on behalf of the European Geosciences Union. 
From a punctual observation, it is difficult to generalize because within a given area, temporal and vertical variability have been shown (Sala et al., 2002; Van Wambeke et al., 2002). In addition, the simple point of view of "one single" resource limiting factor has evolved: i) co-limitation often occurs: carbon - iron (Tortell et al., 1999; Church et al., 2000; Kirchman et al., 2000), carbon - phosphorus (Sala et al., 2002, Van Wambeke et al., 2002), carbon - nitrogen (Torréton et al., 2000) ii) among heterotrophs, organic molecules might acts as nutrients for building biomass but also as energy resources; this observation is at the origin of the concept of energy limitation (Kirchman, 1990, Donachie et al., 2001) and iii) direct versus cascade effects: are bacteria directly stimulated, or do they benefit from a surplus phytoplankton production also affected by the relieving of one key nutrient? (Palkuski et al., 1996; Church et al., 2000; Cochlan, 2001; Oliver et al., 2004; Obernosterer et al., 2008b).

In the South Pacific Gyre, extreme isolation from terrestrial influence results in a permanent situation of hyperoligotrophy (Claustre et al., 2008). Picoplanktonic organisms, both heterotrophic and photoautotrophic, dominate community metabolism in this area (Grob et al., 2007). Bacterial production is very low in the centre of the gyre and relies upon autochthonous, photosynthetically derived organic matter as well as on changes in solar radiations as shown by the diel variability of bacterial production (Van Wambeke et al., 2008a; b). Photo-autotrophic production is limited by nitrogen availability within the centre of the Gyre and is particularly adapted to the very low amounts of dissolved iron present (Bonnet et al., 2008). In contrast, iron limits phytoplanktonic production within the Marquesas plateau. In addition, bulk DOC stock is particularly important in the south Pacific Gyre (Raimbault et al., 2008). One might expect dynamics of bacterial production to be also affected by the lack of inorganic nutrients or iron and the limiting factors to change across this vast, unexplored region of the eastern south Pacific. The purpose of this study was thus to determine which factors limited heterotrophic bacterial growth across a broad survey along longitudinal and vertical gradients from Marquesas Plateau to the Chilean upwelling.

\section{Materials and methods}

To follow bottom-up factors controlling heterotrophic bacteria, prefiltration of samples should be ideal. However, particularly in oligotrophic environments, organic material devoted to bacterial growth is provided continuously through regenerating processes by higher size-class organisms, so that bottom up control is influenced by preying organisms. This is particularly evidenced within the center of the south Pacific Gyre site where the Redfield $\mathrm{f}$ ratio is close to zero, but becomes slightly positive only when considering atmospheric di-nitrogen fixation (Raimbault and Garcia, 2008). In this case, the response of all members of the community is needed to fully appreciate the complexity of changes in trophic regulations and nutrient transfers resulting from addition of nutrients. Another problem is the representativeness of the activity associated to a pre-filtered bacterial fraction (within the gyre, on average $36 \%$ of the bacterial production was associated to the $>0.6 \mu \mathrm{m}$ fraction, unpub. results). Finally, we chose to maintain whole seawater samples to keep the possibility to study simultaneously effect of amendments on both autotrophic and heterotrophic compartment and to explore potentially direct versus indirect effects.

In order to identify the factors limiting heterotrophic bacterial production, two different sets of experiments were performed, one under trace metal clean condition (TMC), and the other under non trace metal clean conditions (non TMC).

\subsection{TMC}

These experiments were performed at four experimental sites. These stations represented different trophic regimes (Table 1): the mesotrophic area associated to the plume of the Marquesas Island $\left(141.14^{\circ} \mathrm{W}, 8.19^{\circ} \mathrm{S}\right)$ (MAR), the adjacent medium nitrate, low chlorophyll waters $\left(136.97^{\circ} \mathrm{W}\right.$, $\left.9.04^{\circ} \mathrm{S}\right)(\mathrm{HNL})$, the hyperoligotrophic waters associated with the central part of the South Pacific gyre $\left(114.02^{\circ} \mathrm{W}\right.$, $\left.26.04^{\circ} \mathrm{S}\right)(\mathrm{GYR})$ and the oligotrophic eastern side of the gyre $\left(91.39^{\circ} \mathrm{W}, 31.89^{\circ} \mathrm{S}\right)(\mathrm{EGY})$. The GYR site has been selected from ocean color images as having the lowest surface chlorophyll concentration in the world ocean. Details of these on-deck incubations are fully described in Bonnet et al. (2008). All experimental setups were performed using strict trace metal clean techniques (Bruland et al., 1979) inside a clean container. Briefly, seawater was collected at 30-meter depth using a Teflon pump system and dispensed into acid-washed (Suprapur Merck HCL) transparent polycarbonate bottles. Under a laminar flow hood, nutrients were added alone and in combination to final concentrations of $1 \mu \mathrm{MNH}_{4}^{+}$(from ammoniac reagent) $+2 \mu \mathrm{MNaNO}_{3}$, $0.3 \mu \mathrm{M} \mathrm{NaH}_{2} \mathrm{PO}_{4}, 2 \mathrm{nM} \mathrm{FeCl}_{3}, 10 \mu \mathrm{MC}$-glucose (Table 2). The bottles were incubated in an on-deck incubator with circulating surface seawater at appropriated irradiance (50\% ambient light level). The difference between circulated surface water temperature and $30 \mathrm{~m}$ depth temperature was negligible at the three sites investigated (no more than $1^{\circ} \mathrm{C}$ ). Three bottles for each treatment were randomly selected and sampled destructively at $24 \mathrm{~h}$ and $48 \mathrm{~h}$. A large set of parameters were measured to follow nutrient concentrations, phytoplankton response (cytometric counts, variable fluorescence, chlorophyll, particulate primary production, Bonnet el al., 2008), bacterial abundance and heterotrophic bacterial production.

\subsection{Non TMC}

We also investigated more systematically factors influencing leucine incorporation rates using non TMC 
Table 1. Initial conditions of "trace metal clean" experiments.

$\mathrm{BN}$ : bacterial abundances.

PP: primary production.

\begin{tabular}{lccccccccccc}
\hline & $\mathrm{T}^{\circ} \mathrm{C}$ & $\mathrm{NO}_{3}$ & $\mathrm{NH}_{4}$ & $\mathrm{PO}_{4}$ & $\mathrm{SiOH}_{4}$ & $\mathrm{Fe}$ & $\mathrm{DOC}^{*}$ & $\mathrm{Chl}-a$ & $\mathrm{PP}$ & BN & leu inc rate \\
\hline & & $\mu \mathrm{M}$ & $\mu \mathrm{M}$ & $\mu \mathrm{M}$ & $\mu \mathrm{M}$ & $\mathrm{nM}$ & $\mu \mathrm{M}$ & $\mathrm{mg} \mathrm{m}^{-3}$ & $\mathrm{mgC} \mathrm{m}^{-3} \mathrm{~d}^{-1}$ & $\times 10^{5} \mathrm{ml}^{-1}$ & $\mathrm{pmol} \mathrm{L}^{-1} \mathrm{~h}^{-1}$ \\
MAR & 27.7 & 1.97 & 0.32 & 0.37 & 0.97 & 0.13 & 70 & 0.18 & $\mathrm{nd}$ & 9.6 & 26 \\
$\mathrm{HNL}$ & 27.7 & 1.82 & 0.04 & 0.31 & 0.91 & 0.14 & 70 & 0.11 & 9.1 & 8.9 & 27 \\
GYR & 22.1 & bdl & bdl & 0.11 & 0.55 & 0.1 & 118 & 0.03 & 1.8 & 4.1 & 18 \\
EGY & 18.0 & 0.04 & 0.008 & 0.17 & 1.02 & 0.1 & 98 & 0.07 & 6.5 & 7.5 & 15 \\
\hline
\end{tabular}

nd: not determined,

bdl: below detection limits, $\mathrm{T}^{\circ} \mathrm{C}$ : temperature

* DOC concentrations come from the analysis of sea water sample collected at the nearest (in time) CTD cast.

Table 2. Summary of enrichment conditions.

Fe: iron, $\mathrm{NH}_{4}$ : ammonium, $\mathrm{NO}_{3}$ : nitrate, $\mathrm{Si}$ : orthosilicic acid, $\mathrm{PO}_{4}$ : phosphate, GLU: glucose.

\begin{tabular}{|c|c|c|c|c|c|c|c|c|}
\hline experiment & code & $\mathrm{Fe}$ & $\mathrm{NH}_{4}$ & $\mathrm{NO}_{3}$ & $\mathrm{Si}$ & $\mathrm{PO}_{4}$ & C-GLU & Incubation sampling \\
\hline \multirow[t]{4}{*}{ MAR* } & $\mathrm{C}$ & & & & & & & \multirow{4}{*}{$24-48 \mathrm{~h}$ in situ simulated $50 \%$ light screen } \\
\hline & $\mathrm{Fe}$ & $2 \mathrm{nM}$ & & & & & & \\
\hline & $\mathrm{N}$ & & $1 \mu \mathrm{M}$ & $2 \mu \mathrm{M}$ & $2 \mu \mathrm{M}^{* *}$ & $0.3 \mu \mathrm{M}$ & & \\
\hline & all & $2 \mathrm{nM}$ & $1 \mu \mathrm{M}$ & $2 \mu \mathrm{M}$ & $2 \mu \mathrm{M}^{* *}$ & $0.3 \mu \mathrm{M}$ & & \\
\hline \multirow[t]{6}{*}{$\mathrm{HNL}^{*}$} & $\mathrm{C}$ & & & & & & & \multirow{6}{*}{$24-48 \mathrm{~h}$ in situ simulated $50 \%$ light screen } \\
\hline & $\mathrm{Fe}$ & $2 \mathrm{nM}$ & & & & & & \\
\hline & $\mathrm{N}$ & & $1 \mu \mathrm{M}$ & $2 \mu \mathrm{M}$ & $2 \mu \mathrm{M}^{* *}$ & $0.3 \mu \mathrm{M}$ & & \\
\hline & $\mathrm{FeN}$ & $2 \mathrm{nM}$ & $1 \mu \mathrm{M}$ & $2 \mu \mathrm{M}$ & $2 \mu \mathrm{M}^{* *}$ & $0.3 \mu \mathrm{M}$ & & \\
\hline & G & & & & & & $10 \mu \mathrm{M} \mathrm{C}$ & \\
\hline & $\mathrm{GFe}$ & $2 \mathrm{nM}$ & & & & & $10 \mu \mathrm{M} \mathrm{C}$ & \\
\hline GYR* & $\mathrm{C}$ & & & & & & & \multirow{7}{*}{$24-48 \mathrm{~h}$ in situ simulated $50 \%$ light screen } \\
\hline \multirow[t]{6}{*}{$\mathrm{EGY}^{*}$} & $\mathrm{Fe}$ & $2 \mathrm{nM}$ & & & & & & \\
\hline & $\mathrm{N}$ & & $1 \mu \mathrm{M}$ & $2 \mu \mathrm{M}$ & & & & \\
\hline & $\mathrm{FeN}$ & $2 \mathrm{nM}$ & $1 \mu \mathrm{M}$ & $2 \mu \mathrm{M}$ & & & & \\
\hline & all & $2 \mathrm{nM}$ & $1 \mu \mathrm{M}$ & $2 \mu \mathrm{M}$ & & $0.3 \mu \mathrm{M}$ & & \\
\hline & G & & & & & & $10 \mu \mathrm{M} \mathrm{C}$ & \\
\hline & $\mathrm{GFe}$ & $2 \mathrm{nM}$ & & & & & $10 \mu \mathrm{M} \mathrm{C}$ & \\
\hline routine & $\mathrm{C}$ & & & & & & & \multirow{5}{*}{$24 \mathrm{~h}$ in situ simulated $50 \%$ light screen } \\
\hline \multirow[t]{4}{*}{ bioassays $* * *$} & $\mathrm{P}$ & & & & & $0.25 \mu \mathrm{M}$ & & \\
\hline & $\mathrm{N}$ & & $1 \mu \mathrm{M}$ & $1 \mu \mathrm{M}$ & & & & \\
\hline & G & & & & & & $10 \mu \mathrm{M}$ & \\
\hline & NPG & & $1 \mu \mathrm{M}$ & $1 \mu \mathrm{M}$ & & $0.25 \mu \mathrm{M}$ & $10 \mu \mathrm{M}$ & \\
\hline
\end{tabular}

* "trace metal clean" conditions of manipulation.

** $\mathrm{Si}$ addition resulted in a slight contamination in $\mathrm{Fe}$ of about $0.1 \mathrm{nM}$.

*** non "trace metal clean" conditions of manipulation. 


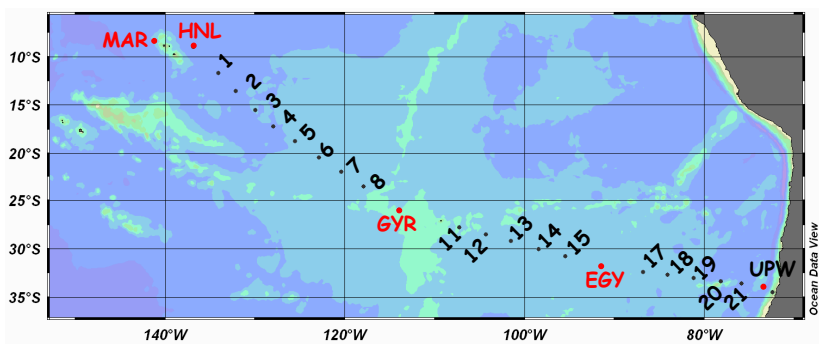

Fig. 1. Transect of the BIOSOPE cruise from the Marquesas Islands to Chile. In red, stations where "trace metal clean" enrichment experiments were processed, in black, stations used for "non metal clean" bioassays. Numbers indicate short-term stations, for which only numbers have been indicated to simplify presentation, not the complete code as in Table 3. For instance 1 is STB1 and 21 is STA21.

experiments, i.e. incubated water sampled from Niskin bottles and manipulated in a classical laboratory. Nutrients were added in order to obtain a final concentration of $1 \mu \mathrm{M} \mathrm{NH}_{4} \mathrm{Cl}+1 \mu \mathrm{M} \mathrm{NaNO}_{3}, 0.25 \mu \mathrm{M} \mathrm{Na}_{2} \mathrm{HPO}_{4}, 10 \mu \mathrm{MC}-$ glucose (Table 2). Transparent polycarbonate flasks of $60 \mathrm{ml}$ were used and incubated on average $24 \mathrm{~h}$ in simulated in situ conditions (on deck incubator, neutral screens). For the longitudinal trend $\left(141^{\circ} \mathrm{W}\right.$ to $72^{\circ} \mathrm{W}$, Fig. 1$)$, seawater was sampled at one single depth varying from 5 to $30 \mathrm{~m}$ according the CTD profile. The depths chosen were always within the mixed layer, and corresponded to 50\% incident light. We also investigated factors limiting BP along vertical profiles at sites GYR, EGY and UPW. The latter site corresponded to the upwelling area off the Chilean Coast $\left(73.2^{\circ} \mathrm{W}, 33.5^{\circ} \mathrm{S}\right.$, Fig. 1). For those experiments, for each depth sampled, five $60 \mathrm{ml}$ polycarbonate flasks (C, P, N, G, NPG) were incubated in a running seawater bath covered with a neutral screen corresponding to the incident light level. The deeper depth sampled was below the euphotic zone and was incubated in the dark in the incubator at in situ temperature. In situ light conditions were then correctly reproduced (excluding UV effects), whereas a slight difference could be obtained with temperature: up to $3^{\circ} \mathrm{C}$ difference at GYR (for the $185 \mathrm{~m}$ sample corresponding to $1 \%$ incident light: $19^{\circ} \mathrm{C}$ in situ, $22^{\circ}$ during incubation), $2^{\circ} \mathrm{C}$ at $\mathrm{EGY}$ and $2.2^{\circ}$ at UPW.

Samples for bacterial abundances were fixed with paraformaldehyde at $1 \%$ and quick frozen in liquid nitrogen. Within 2 months after the cruise, they were analyzed with SYBR Green I and run on a FACSCalibur flow cytometer as described in Grob et al. (2007). Bacterial production was determined using ${ }^{3} \mathrm{H}$ leucine technique coupled with the centrifuge method with full methodological description in Van Wambeke et al. (2008a). Briefly, $1.5 \mathrm{ml}$ seawater samples or sub-samples from incubated flasks were incubated in the dark for 1 to $2 \mathrm{~h}$ after addition of $20 \mathrm{nM}$ leucine. The terms "heterotrophic bacteria" and "heterotrophic bacterial production" are used in the whole text by simplicity but sensus stricto refers to heterotrophic prokaryotes and heterotrophic prokaryotic production, respectively. Indeed, prokaryotes include Bacteria and Archaea; and it has been shown that some organisms in both groups are able to incorporate leucine (Kirchman et al., 2007).

Nutrients were analyzed following standard colorimetric methods on board (Raimbault et al., 2008). Chlorophylla (Chl- $a$ ) concentrations given for the enrichment experiments were analyzed fluorimetrically as described in Bonnet et al. (2008) whereas pigment concentrations were measured systematically at each station during the transect using HPLC method (Ras et al., 2008). Particulate primary production was measured on board in running seawater baths covered with a $50 \%$ neutral screen. Incubations periods lasted on average $5 \mathrm{~h}$ during morning time hours. Detailed methodology and assumption used to convert hourly to daily rates are fully described in Duhamel et al. (2007).

We used a non parametric test, the Mann-Whitney test in TMC experiments. Because this test lacks statistical power with small samples, we used it only when triplicate data where available in order to maintain comparison purpose. When comparing the effect of one enrichment to the control on a given variable, untransformed data were compared. When comparing the degree of stimulation reached for one given enrichment between 2 variables, the enrichment factor (i.e., ratio of rate (or stock) in enriched batch to the rate (or stock) in control unamended) were compared. The Wilcoxon signed-rank test was used in non TMC experiments.

\section{Results}

\subsection{Initial conditions prior to enrichment experiments}

A large gradient of nutrient concentrations and chlorophyll a was observed along the transect (Table 3). Nitrate concentrations ranged from undetectable values to $3.6 \mu \mathrm{M}$ (station STB 18), whereas soluble reactive phosphorus was always detectable and above $120 \mathrm{nM}$ (Moutin et al., 2008). Chla varied almost by 2 orders of magnitude $\left(0.02 \mathrm{mg} \mathrm{m}^{-3}\right.$ in the centre of the gyre to $14.8 \mathrm{mg} \mathrm{m}^{-3}$ in the Chilean upwelling system). Leucine incorporation rates ranged from 10 to $164 \mathrm{pmol} \mathrm{L}^{-1} \mathrm{~h}^{-1}$. Higher values of nutrients, Chl- $a$ and leucine incorporation rates were obtained at the eastern part of the transect, within the Chilean upwelling (stations STB20, STA21, site UPW). Stations between STB6 and STB15 displayed lower Chl- $a$ stocks and leucine incorporation rates (means $\pm \mathrm{sd} 0.027 \pm 0.009 \mathrm{mg} \mathrm{Chl}-a \mathrm{~m}^{-3}$, $11.9 \pm 1.2 \mathrm{pmol} \mathrm{L}^{-1} \mathrm{~h}^{-1}$, respectively). Vertical profiles of dissolved iron indicated low $(0.13 \pm 0.03 \mathrm{nM})$ and constant concentrations from the surface to $80 \mathrm{~m}$ throughout most of the transect (site STB4 to STB14, including GYR), and increased notably from station STA21 to the Chilean coast, to reach 0.4 to $1.2 \mathrm{nM}$ in surface waters (also see Blain et al., 2008). 
Table 3. Initial conditions prevailing in sea water samples used for routine bioassays. SST: sea surface temperature (used in running sea water baths during incubations), Chl $a$ : Chlorophyll $a$, Leu inc rate: incorporation rates of leucine into proteins, ld: below detection limits.

\begin{tabular}{|c|c|c|c|c|c|c|c|c|c|c|}
\hline station & $\begin{array}{l}\text { depth } \\
\text { m }\end{array}$ & $\begin{array}{l}\text { Longitude } \\
{ }^{\circ} \mathrm{W}\end{array}$ & $\begin{array}{l}\text { Latitude } \\
\circ \mathrm{S}\end{array}$ & date & $\begin{array}{l}\mathrm{SST} \\
{ }^{\circ} \mathrm{C}\end{array}$ & $\begin{array}{l}\mathrm{NO}_{3} \\
\mu \mathrm{M}\end{array}$ & $\begin{array}{l}\mathrm{NH}_{4} \\
\mu \mathrm{M}\end{array}$ & $\begin{array}{l}\mathrm{PO}_{4} \\
\mathrm{nM}\end{array}$ & $\begin{array}{l}\text { Chl- } a \\
\mathrm{mg} \mathrm{m}^{-3}\end{array}$ & $\begin{array}{l}\text { Leu inc rate } \\
\text { pmol } L^{-1} h^{-1}\end{array}$ \\
\hline MAR & 5 & $141^{\circ} 14$ & $08^{\circ} 19$ & 29-oct. & & $1.68^{*}$ & $0.33^{*}$ & & 0.168 & 50.9 \\
\hline STB1 & 10 & $134^{\circ} 05$ & $11^{\circ} 44$ & 3-nov. & 27.8 & $0.70(5 \mathrm{~m})$ & 0.03 & 313 & 0.112 & 30.9 \\
\hline STB2 & 15 & $132^{\circ} 06$ & $13^{\circ} 33$ & 4-nov. & 27.4 & ld & 0.01 & 208 & 0.088 & 29 \\
\hline STB3 & 15 & $129^{\circ} 55$ & $15^{\circ} 32$ & 5-nov. & 27.1 & 0.046 & 0.004 & 193 & 0.055 & 21.4 \\
\hline STB4 & 15 & $127^{\circ} 58$ & $17^{\circ} 14$ & 6-nov. & 26.5 & ld & ld & 213 & 0.050 & 21 \\
\hline STB5 & 20 & $125^{\circ} 33$ & $18^{\circ} 44$ & 7-nov. & 25.7 & ld & ld & 163 & 0.038 & 15.9 \\
\hline STB6 & 25 & $122^{\circ} 53$ & $20^{\circ} 27$ & 8-nov. & 24.5 & ld & 0.008 & 178 & 0.018 & 11.9 \\
\hline STB7 & 20 & $120^{\circ} 22$ & $22^{\circ} 03$ & 9-nov. & 24.3 & 0.046 & ld & 143 & 0.022 & 13.4 \\
\hline STB8 & 30 & $117^{\circ} 53$ & $23^{\circ} 33$ & 10-nov. & 23.4 & ld & ld & 128 & 0.026 & 12.4 \\
\hline GYR & 30 & $114^{\circ} 00$ & $25^{\circ} 58$ & 12-nov. & 22.1 & ld & $0.02 *$ & 128 & 0.028 & 10.8 \\
\hline STB11 & 30 & $107^{\circ} 17$ & $27^{\circ} 46$ & 20-nov. & 21.3 & ld & $\mathrm{ld}^{*}$ & 123 & 0.032 & 12.4 \\
\hline STB12 & 30 & $104^{\circ} 18$ & $28^{\circ} 32$ & 21-nov. & 21.2 & ld & $0.001^{*}$ & 133 & 0.022 & 11.2 \\
\hline STB13 & 25 & $101^{\circ} 28$ & $29^{\circ} 13$ & 22-nov. & 20 & ld & $0.003^{*}$ & 123 & 0.023 & 10.6 \\
\hline STB14 & 20 & $98^{\circ} 23$ & $30^{\circ} 02$ & 23-nov. & 19.8 & 0.048 & $\mathrm{ld}^{*}$ & 138 & 0.027 & 10.5 \\
\hline STB15 & 15 & $95^{\circ} 25$ & $30^{\circ} 47$ & 24-nov. & 18.7 & ld & $0.015^{*}$ & 153 & 0.048 & 13.9 \\
\hline EGY & 15 & $91^{\circ} 27$ & $31^{\circ} 49$ & 26-nov. & 18.1 & $0.006^{*}$ & $0.006^{*}$ & 178 & 0.074 & 17 \\
\hline STB17 & 15 & $86^{\circ} 47$ & $32^{\circ} 23$ & 1-dec. & 17.3 & $2.65^{*}$ & $0.116^{*}$ & $313^{*}$ & 0.116 & 20.3 \\
\hline STB18 & 15 & $84^{\circ} 04$ & $32^{\circ} 40$ & 2-dec. & 17.4 & 3.64 & $0.119^{*}$ & 388 & $0.147^{*}$ & 16.6 \\
\hline STB19 & 15 & $81^{\circ} 12$ & $33^{\circ} 01$ & 3-dec. & 17.2 & 2.76 & $0.132^{*}$ & 373 & 0.066 & 17.5 \\
\hline STB20 & 5 & $78^{\circ} 07$ & $33^{\circ} 21$ & 4-dec. & 17.6 & 0.095 & & 268 & 0.274 & 51.5 \\
\hline STA21 & 5 & $75^{\circ} 49$ & $33^{\circ} 36$ & 5-dec. & 16.8 & 0.071 & & 358 & 0.218 & 54.6 \\
\hline UPW1 & 5 & $73^{\circ} 22$ & $33^{\circ} 59$ & 6-dec. & 15.9 & & & & $1.481^{*}$ & 145.4 \\
\hline UPW2 & 5 & $73^{\circ} 21$ & $33^{\circ} 55$ & 7-dec. & & 0.289 & & 508 & 1.394 & 163.7 \\
\hline
\end{tabular}

* refers to data acquired on another CTD cast sampled in an interval of few hours on the same site.

\subsection{TMC experiments}

\subsubsection{Heterotrophic versus autotrophic response.}

The extent of stimulation of phytoplankton and bacterial biomasses and productions following various amendments varied according to the station and the element tested. Roughly, phytoplankton was significantly stimulated by $\mathrm{Fe}$ addition alone but also $\mathrm{N}$ addition alone at the MAR and HNL sites, by $\mathrm{N}$ at the GYR site, and responded mostly to $\mathrm{Fe}+\mathrm{N}(\mathrm{FeN}$, all) additions at the EGY site (Table 4). Leucine incorporation rate was particularly stimulated by glucose at the HNL site and by N at the GYR site. Stimulations were less significant at MAR and EGY sites: Fe alone, but also N alone stimulated leucine activity at the MAR site, whereas it was glucose at the EGY site (Fig. 2, Table 4).

Besides the information concerning the limiting factor(s), we obtained the following general features: bacterial numbers did not increase or, when increasing, always increased less than leucine incorporation rates (HNL site in G and GFe, $p<0.05$ for all comparisons of enrichment factors). Chlorophyll stocks either increased in the same proportion as the primary production (GYR $24 \mathrm{~h}$ in N, FeN and all for instance), or increased in less proportion than primary produc-
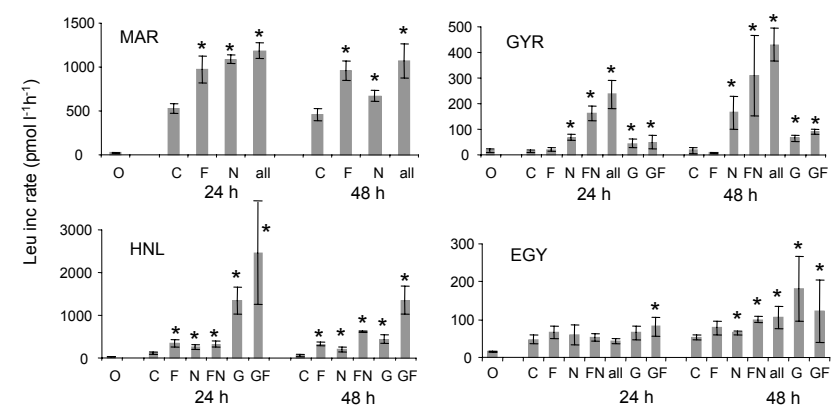

Fig. 2. Evolution of leucine incorporation rates on bioassay experiments made under "trace metal clean" conditions. Means \pm sd of triplicate bottles sampled after 24 and $48 \mathrm{~h}$ of incubations. For MAR and HNL enrichments were $\mathrm{O}$ : initial conditions, $\mathrm{C}$ : control non enriched, F:+iron, N:+ nitrates+ammonium+phosphates+silicates, all: nitrates+phosphates+silicates+iron, G:+glucose, GF:glucose+iron. For GYR and EGY $\mathrm{N}$ was only nitrate+ammonium, $\mathrm{FN}$ was nitrate+ammonium+iron and all nitrates+ammonium+phosphates+iron . * : response significantly different from the control at the same time, Mann Whitney test, $p<0.05$. 
Table 4. Summary of the factors of increase obtained after 24 and $48 \mathrm{~h}$ incubations in "trace metal clean" experiments. Results are expressed as the ratio of the mean value obtained divided by the mean value obtained in the non-amended control at the same time. For the lines corresponding to non-amended controls $(\mathrm{C})$, the italic values indicate the factor of increase relative to the control at time zero. Enrichment codes correspond to Table 2. The parameters and their units before comparison are: chlorophyll- $a\left(\mathrm{Chl}-a, \mathrm{mg} \mathrm{m}^{-3}\right)$, bacterial abundance $\left(\mathrm{BN}\right.$, cells $\mathrm{ml}^{-1}$ ), heterotrophic nanoflagellate abundances (HNAN, cells $\left.\mathrm{ml}^{-1}\right),{ }^{14} \mathrm{C}$-primary production $\left(\mathrm{PP}, \mathrm{mg} \mathrm{C} \mathrm{m}^{-3} \mathrm{~d}^{-1}\right), \mathrm{leucine}$ incorporation rates (Leu pmol L $\mathrm{L}^{-1} \mathrm{~h}^{-1}$ ), primary production per unit Chl- $a$ (spec PP, mgC mg Chl $a^{-1} \mathrm{~d}^{-1}$ ) and leucine incorporation rate per cell (spec Leu, $\times 10^{-21}$ mol cell ${ }^{-1} \mathrm{~h}^{-1}$ ). Empty places: parameter not sampled.

\begin{tabular}{|c|c|c|c|c|c|c|c|c|c|c|c|c|c|c|c|}
\hline & & \multicolumn{5}{|c|}{$24 \mathrm{~h}$} & \multicolumn{9}{|c|}{$48 \mathrm{~h}$} \\
\hline & & Chl- $A$ & $\mathrm{BN}$ & HNAN & PP & Leu & sp PP & sp Leu & Chl- $A$ & $\mathrm{BN}$ & HNAN & PP & Leu & sp PP & sp Leu \\
\hline \multirow[t]{4}{*}{ MAR } & $\mathrm{C}$ & 1.5 & 1.1 & & & 20.1 & & 17.6 & 2 & & & & 17.4 & & \\
\hline & $\mathrm{Fe}$ & $1.6^{* *}$ & $1.1^{* *}$ & & & $1.8^{* *}$ & & $1.7^{* *}$ & 3.0 ${ }^{* *}$ & & & & $2.1^{* *}$ & & \\
\hline & $\mathrm{N}$ & $1.7^{* *}$ & $1.1^{* *}$ & & & $2.1^{* *}$ & & $1.8^{* *}$ & $1.7^{* *}$ & & & & $1.5^{* *}$ & & \\
\hline & all & $2.2^{* *}$ & $1.2^{* *}$ & & & $2.2^{* *}$ & & $2.0^{* *}$ & $8.7^{* *}$ & & & & $2.3^{* *}$ & & \\
\hline \multirow[t]{6}{*}{ HNL } & $\mathrm{C}$ & $1.4^{* *}$ & $1.1^{* *}$ & 1.2 & 1.1 & $4.2^{* *}$ & $0.8^{* *}$ & $3.8^{* *}$ & $1.3^{* *}$ & $1.2^{* *}$ & 1.3 & $0.8^{* *}$ & $2.6^{* *}$ & $0.6^{* *}$ & 2.2 \\
\hline & $\mathrm{Fe}$ & $1.4^{* *}$ & 1 & 1.1 & $2.8^{* *}$ & $3.1^{* *}$ & $2.0^{* *}$ & 3.3** & $3.6^{* *}$ & 0.9 & 1.2 & $5.5^{* *}$ & $4.6^{* *}$ & $1.5^{* *}$ & $5^{* *}$ \\
\hline & $\mathrm{N}$ & $1.9^{* *}$ & 1 & 1.8 & $3.9^{* *}$ & $2.3^{* *}$ & $2.1^{* *}$ & $2.2^{* *}$ & 4.5 & 1 & 2.1 & $5.7^{* *}$ & $2.7^{* *}$ & 1.1 & $2.7^{* *}$ \\
\hline & $\mathrm{FeN}$ & $1.9^{* *}$ & 0.9 & 1.7 & $4.3^{* *}$ & $2.9^{* *}$ & $2.3^{* *}$ & 3.1 ** $^{* *}$ & 6.1 & 1 & 2 & $9.5^{* *}$ & $8.7^{* *}$ & 1.4 & $9.1^{* *}$ \\
\hline & G & & $1.1^{* *}$ & 1.4 & & $11.9^{* *}$ & & $10.5^{* *}$ & & $1.1^{* *}$ & 1.4 & & $6.3^{* *}$ & & 5.5 F* $^{* *}$ \\
\hline & Gfe & & $1.2^{* *}$ & 1.2 & & $21.7^{* *}$ & & $18.8^{* *}$ & & $1.1^{* *}$ & 1.4 & & $19.1^{* *}$ & & $16.3^{* *}$ \\
\hline \multirow[t]{7}{*}{ GYR } & $\mathrm{C}$ & 1.1 & 0.9 & 1.1 & $0.4^{* *}$ & 0.8 & 0.4 & 0.9 & 0.7 & & 1.1 & $0.5^{* *}$ & 1 & 0.7 & \\
\hline & $\mathrm{Fe}$ & 1.5 & 1 & 1 & 1.1 & 1.4 & 0.6 & 1.4 & 1 & & 1 & $0.7^{* *}$ & 0.5 & 0.7 & \\
\hline & $\mathrm{N}$ & $2.2^{* *}$ & 1 & 1.1 & $2.1^{* *}$ & $\mathbf{4 . 6}^{* *}$ & 0.9 & $4.7^{* *}$ & 3.1 & & 1.4 & $4.2^{* *}$ & $8.9^{* *}$ & 1.4 & \\
\hline & $\mathrm{FeN}$ & $2.3^{* *}$ & 1 & 1.1 & $2.4^{* *}$ & $11.0^{* *}$ & 1.1 & $11.0^{* *}$ & 4 & & 1.6 & $5.4^{* *}$ & $16.9^{* *}$ & 1.4 & \\
\hline & all & $2.1^{* *}$ & 1 & 2 & 2.0 $0^{* *}$ & $16.0^{* *}$ & 0.9 & $15.9^{* *}$ & 3.3 & & 1.8 & $4.5^{* *}$ & $23.4^{* *}$ & 1.4 & \\
\hline & G & & 1 & 1.1 & & $\mathbf{3}^{* *}$ & & 3.1 & & & 1.4 & & $3.5^{* *}$ & & \\
\hline & $\mathrm{GFe}$ & & 1 & 1 & & $3.4^{* *}$ & & $3.5^{* *}$ & & & 1.5 & & $4.9^{* *}$ & & \\
\hline \multirow[t]{7}{*}{ EGY } & $\mathrm{C}$ & $1.9^{* *}$ & 1.1 & 1.1 & $0.7^{* *}$ & $3.1^{* *}$ & $0.4^{* *}$ & 2.7 & $1.8^{* *}$ & 1.1 & 1.1 & $0.8^{* *}$ & $3.5^{* *}$ & $0.4^{* *}$ & 3.1 \\
\hline & $\mathrm{Fe}$ & 0.9 & 1 & 1.2 & 1 & 1.4 & 1.1 & 1.4 & 1.4 & 1.1 & 1.6 & $1.3^{* *}$ & 1.5 & 1.3 & 1.3 \\
\hline & $\mathrm{N}$ & $1.2^{* *}$ & 1 & 1.3 & $1.1^{* *}$ & 1.3 & 0.9 & 1.3 & $1.6^{* *}$ & 1 & 1.9 & $1.9^{* *}$ & $1.2^{* *}$ & $1.2^{* *}$ & $1.2^{* *}$ \\
\hline & $\mathrm{FeN}$ & $1.2^{* *}$ & 1 & 1.2 & $1.5^{* *}$ & 1.1 & 1 & 1.1 & $2.6^{* *}$ & 1 & 2 & $3.8^{* *}$ & $1.9^{* *}$ & $1.5^{* *}$ & $1.8^{* *}$ \\
\hline & all & $1.3^{* *}$ & 1 & 1.6 & $1.8^{* *}$ & 0.9 & $1.4^{* *}$ & 1 & 3.0 ${ }^{* *}$ & 1.2 & 2.4 & $4.5^{* *}$ & $\mathbf{2}^{* *}$ & $1.5^{* *}$ & $1.7^{* *}$ \\
\hline & G & & 1 & 1.2 & & 1.4 & & 1.4 & & 1 & 1.4 & & $3.5^{* *}$ & & $3.4^{* *}$ \\
\hline & $\mathrm{GFe}$ & - & 1 & 1.1 & & $1.8^{* *}$ & & $1.7^{* *}$ & & 1 & 1.7 & - & 2.3 & & 2.4 \\
\hline
\end{tabular}

\footnotetext{
** Indicates a response significantly different at $p<0.05$ after Mann Whitney test. This test was made only when triplicate data were available
} for both pairs of data set compared (bold characters).

tion (HNL $24 \mathrm{~h}$ in Fe, N, FeN; HNL $48 \mathrm{~h}$ in Fe; GYR $48 \mathrm{~h}$ in $\mathrm{N}, \mathrm{FeN}$; EGY $48 \mathrm{~h}$ in $\mathrm{N}, \mathrm{FeN}$, all, $p<0.05$ for all these comparisons of enrichment factors). In addition, chlorophyll stocks increased after $48 \mathrm{~h}$ up to a factor of 6 (FeN at the HNL site), whereas bacterial abundances never increased more than a factor of 1.2 ("all" at the EGY site, GFe at the HNL site and "all" at the MAR site). Factors of increase of leucine specific activities were consequently very close to those of the fluxes, whereas primary production per unit of chlorophyll, when increasing, increased, on average of $\times 1.6$ less than photosynthesis rates (Table 4).

Out of these general trends, the intensity of the heterotrophic response differed from the intensity of autotrophic response. For instance, at the GYR site, both photosynthesis and heterotrophic production were stimulated after $\mathrm{N}$ additions (alone and combined: N, FeN, "all"), but leucine incorporation rates increased up to 8 times more than primary production (GYR “all”, after $24 \mathrm{~h}, \times 16$ and $\times 2$, respectively, Table 4, all these differences at $24 \mathrm{~h}$ and $48 \mathrm{~h}$ between enrichment factors on leucine activity vs PP were significant at $p<0.05)$. On the opposite, in the treatments $\mathrm{N}(24,48 \mathrm{~h})$ and $\mathrm{FeN}(24 \mathrm{~h})$ at the HNL site, and FeN (24, $48 \mathrm{~h}$ ) and "all"(24, $48 \mathrm{~h}$ ) in the treatments at the EGY site, primary production increased on average 1.6 times more than leucine incorporation rates (differences of enrichment factors significant at $p<0.05$ ). It must be noticed that these latter cases corresponded to situations where phytoplankton and heterotrophic bacteria were not stimulated primarily by the same factor (i.e. $\mathrm{N}$ or $\mathrm{Fe}$ for phytoplankton and glucose for bacteria).

\subsubsection{Iron control on Heterotrophic Bacteria}

At the MAR site, the most significant increase was obtained in the non-amended control ( $\times 20$ in $24 \mathrm{~h}$ ), whereas Fe alone, 
macronutrients $\mathrm{N}+\mathrm{P}+\mathrm{Si}$ ("N") or a combination of all the nutrients $\mathrm{Fe}+\mathrm{N}+\mathrm{P}+\mathrm{Si}$ ("all") lead to similar significant but low response (1.8 to 2.2 times higher than the control at the same time). There was no other additional effect after $48 \mathrm{~h}$. At the HNL site, only the glucose and glucose+Fe additions resulted in a drastic increase of leucine incorporation rates $(\times 11$ and $\times 21$ ), visible $24 \mathrm{~h}$ after enrichment, although significant, but lower stimulations were obtained after $\mathrm{Fe}, \mathrm{N}$, and $\mathrm{FeN}$ enrichments. At the GYR site, $\mathrm{Fe}+\mathrm{N}(\mathrm{FeN})$, and a combination of all the nutrients $\mathrm{Fe}+\mathrm{N}+\mathrm{P}$ (all) resulted in a significantly higher leucine incorporation rates after $24 \mathrm{~h}(\times 11, \times 16$, respectively) and $48 \mathrm{~h}(\times 16, \times 23$, respectively). The leucine incorporation rate was also enhanced after $\mathrm{N}$ addition alone, but on a lower extent, and not by $\mathrm{Fe}$ alone. Glucose (alone or in combination with $\mathrm{Fe}$ ) results in a significant, but low increase of leucine incorporation rate, even after $48 \mathrm{~h}$. At the EGY site, however, only glucose additions stimulated significantly leucine incorporation rates at $24 \mathrm{~h}(\times 1.8$ in GFe at $24 \mathrm{~h}$ ). Significant increases of leucine activity were seen also after $48 \mathrm{~h}$ in N, FeN and "all" $(\times 1.2$ to $\times 1.9)$ but to a lesser extent than after glucose addition $(\times 3.5$, Table 4 , Fig. 2$)$.

The results obtained in the framework of these trace metal clean experiments allowed us to draw some conclusions: i) iron was never a single factor limiting bacterial production, ii) when stimulation by iron occurred, response in the unamended control (MAR site), in glucose amended samples (HNL) was greater, suggesting that the stimulation of bacterial production after iron addition was a cascade effect. Consequently, we assumed that effects of N, P and glucose additions could be studied more systematically along the transect by using "non TMC" technique, and $24 \mathrm{~h}$ incubations should be long enough to detect some stimulation, if occurring.

\subsection{Non TMC experiments}

3.3.1 Longitudinal variability of nutrient control on Heterotrophic Bacteria

Along the horizontal transect in the mixed layer, $\mathrm{P}$ alone stimulated leucine incorporation rates only in 1 case over 23 tested (station STB4, $\times 2.2$ higher than the control). However, in that bioassay the addition of $\mathrm{N}(\times 3.4)$ and $\mathrm{G}$ alone $(\times 2.6)$ also resulted in an increase of leucine incorporation rates. We thus discarded phosphorus as a potentially limiting factor everywhere on the transect. At the opposite, effects of $\mathrm{N}$, glucose and NPG additions on leucine incorporation rates showed three groups of responses. In the western part, from the MAR site to station STB5, the leucine incorporation rate was greatly stimulated simply by confinement during $24 \mathrm{~h}$ in a polycarbonate bottle (see example of STB1, Fig. 3). On average, the median factor of increase of leucine incorporation rates was 39 (Fig. 4a). This is in agreement with the TMC experiments conducted at the MAR site (Fig. 2). The median values of stimulation factors were $\times 1.4, \times 1.1$ and $\times 2.6$ for glucose, N and NPG addition, respectively (Fig $4 b$ ). In this

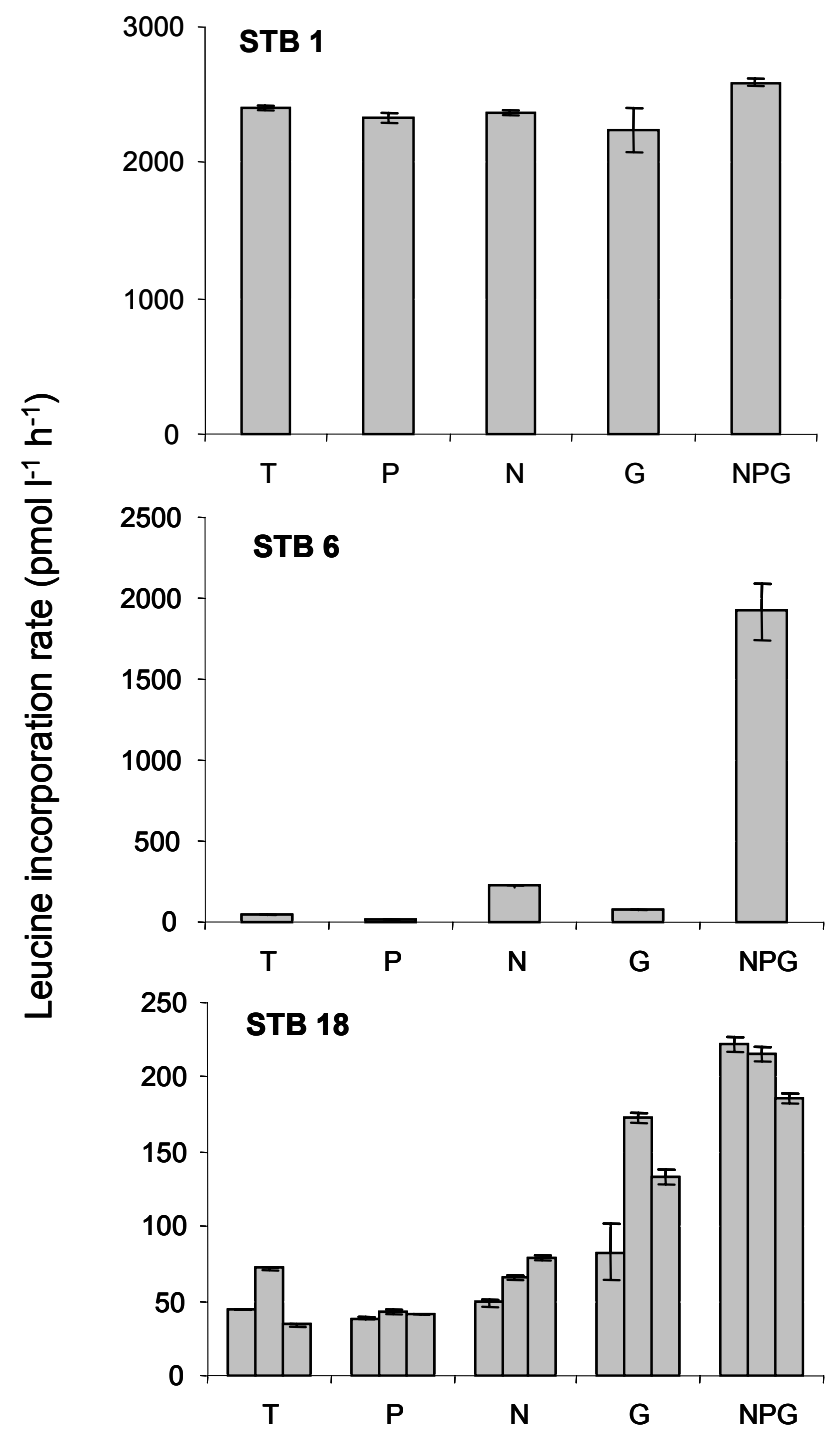

Fig. 3. Typical results obtained from "non metal clean" bioassays. C: control, P:+phosphates, N:+nitrites+nitrates, G:+glucose, NPG: all 4 elements. Error bar represents variability within duplicate leucine measurements in a single flask. At station STB18, triplicate flasks were incubated. Station STB1: no stimulation, STB6: slight stimulation with N, big stimulation with NPG, STB18: stimulation with glucose.

group of stations, the leucine incorporation rates increased significantly only in the control (Wilcoxon signed-rank test, $p<0.05$ ). In the second group of stations (STB6 to STB15, including the GYR site, see example of STB6, Fig. 3), the leucine incorporation rates increased less $(\times 1.1$ to $\times 5.3)$ in the non-amended control (Fig. 4a). The median values of stimulation factors for glucose, N and NPG additions were $\times 1.4, \times 4.2$ and $\times 37.2$, respectively (Fig. $4 b$ ). In this group of stations, the leucine incorporation rates increased significantly in the control, in N and NPG -amended samples (Wilcoxon signed-rank test, $p<0.01$ ). For the last group of 


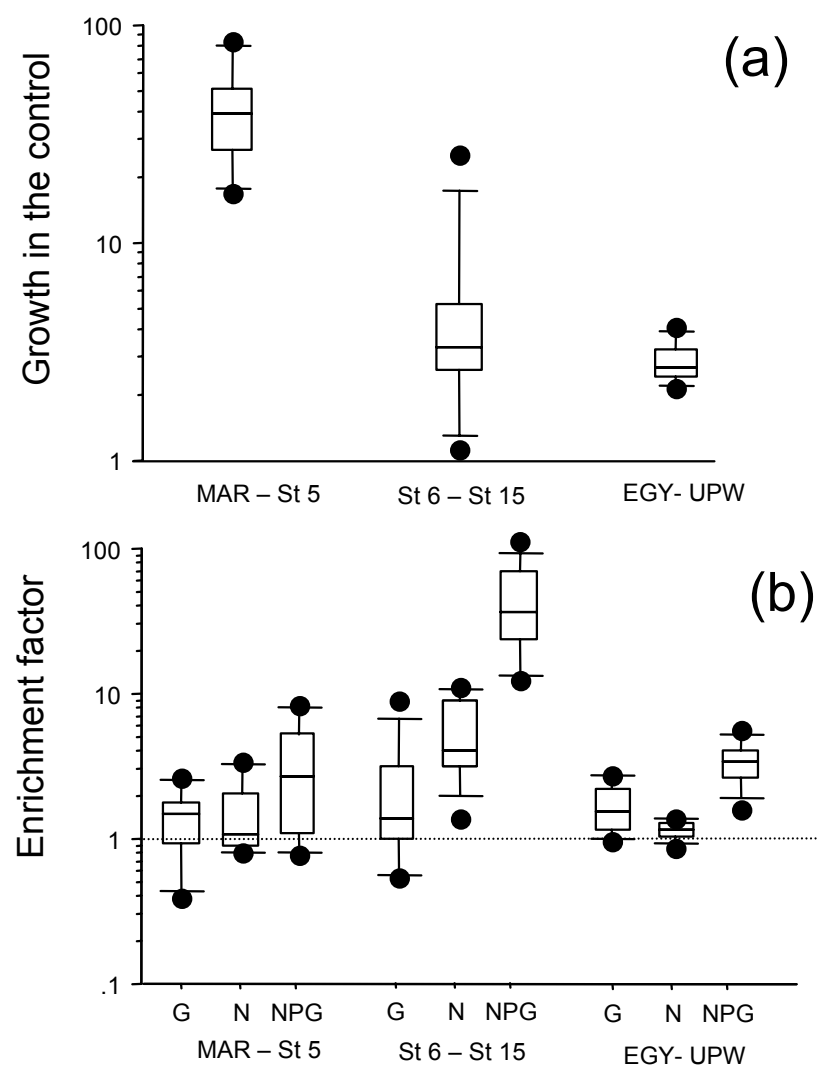

Fig. 4. Mean results on bioassays realized in sub surface waters, varying from $5 \mathrm{~m}$ (MAR, UPW areas) to $30 \mathrm{~m}$ (GYR area). (a) Box-plot distribution of the factor of enrichment in the non enriched control after $24 \mathrm{~h}$ incubation under in situ-simulated conditions. (b) Box-plot distribution of enrichment factors obtained after $24 \mathrm{~h}$ incubation in presence of nitrate+ammonium $(\mathrm{N})$, glucose $(\mathrm{G})$ and phosphates+nitrates+ammonium+glucose (NPG). Enrichment factor is the leucine incorporation rate after $24^{\circ} \mathrm{h}$ amendments compared to the leucine incorporation rate in the non-amended control at the same time. MAR - St 5 group (site MAR and stations STB1 to STB5, $n=6$ ), St 6-St 15 group (stations STB6 to STB8, site GYR, stations STB11 to STB15, n=9), EGY-UPW (site EGY, stations STB17 to STA21, UPW1, UPW2, $n=8$ ). The middle line in the box is the median value. Limits of the box: upper 75th percentile, lower 25th percentile; limits of the error bar: 90th and 10th percentiles; dots: outliers.

stations (EGY to UPW2), the leucine incorporation rates also increased slightly in the non-amended control $(\times 2.1$ to $\times 2.7$ in $24 \mathrm{~h}$ between station EGY and STA21, but $\times 4.1$ and $\times 3.5$ at stations UPW1 and UPW2). The median values of stimulation factors for glucose, N and NPG additions were $\times 1.6$, $\times 1.1$ and $\times 3.4$, respectively (Fig. $4 b$, see example of STB18, Fig. 3). In this last group of stations, the leucine incorporation rates increased significantly in the control, in G and NPG - amended samples (Wilcoxon signed-rank test, $p<0.05$ ).
3.3.2 Vertical variability of nutrient control on Heterotrophic Bacteria

There were also varying stimulation factors of leucine incorporation rates along vertical profiles. At the GYR site, leucine incorporation rates increased after $\mathrm{N}$ addition at all depths tested, even if nitrate was significantly detected below $150 \mathrm{~m}(0.15 \mu \mathrm{M}$ at $185 \mathrm{~m}, 3.6 \mu \mathrm{M}$ at $245 \mathrm{~m}$, Fig. 5). Glucose, however, has a higher effect than $\mathrm{N}$ at $185 \mathrm{~m}(\times 83$ versus $\times 4)$ and $245 \mathrm{~m}(\times 495$ versus $\times 190$, respectively $)$. At the EGY site, the stimulation factor of leucine incorporation rates after $24 \mathrm{~h}$ addition of glucose progressively increased between $80 \mathrm{~m}$ and $250 \mathrm{~m}(\times 4$ up to $\times 105)$. Stimulation by $\mathrm{N}$ alone was non existent or low $(\times 2.2$ at $40 \mathrm{~m}, \times 2.6$ at $250 \mathrm{~m})$, although nitrogen was still undetectable above $40 \mathrm{~m}$. Stimulation by NPG also increased from the surface layer $(\times 1.1-$ $\times 2.9$ above $30 \mathrm{~m})$ to $250 \mathrm{~m}(\times 49)$. At the UPW site, only effects of $\mathrm{G}$ and NPG were visible, being more or less constant and with poor increases (factors $<4$ ) below $10 \mathrm{~m}$. At $5 \mathrm{~m}$ depth, none of the nutrients (alone or in combination) stimulated leucine incorporation rates.

\section{Discussion}

\subsection{Abundance or production to track limitation?}

Because both abundance and leucine incorporation rates have been followed, one question is arising: What is the best indicator for tracking factors limiting heterotrophic bacterial growth? The increase in leucine incorporation rates, when present, is either due to stimulation of a greater percentage of active population, or the stimulation of the specific growth rate of individual cells, or some combination of these two processes, whereas bacterial abundance is also regulated by grazing when intact sea water is manipulated, and should increase more rapidly in pre-filtered samples. Indeed, bacterial abundance responds generally less than production to enrichments in unfiltered samples (Kirchman, 1990; Pomeroy et al., 1995 ; Graneli et al., 2004). In our experiments, bacterial abundances showed a response up to $\times 1.2$ after enrichments, whereas leucine incorporation rates increased up to 23 times (Table 4), confirming these previous results. Within surface water at the GYR site, only $25 \%$ of the "DAPI-labelled bacteria" showed distinct silver grains after microautoradiography coupled to hybridization in situ (Obernosterer et al., 2008a) suggesting inexistent or very low protein synthesis rate by a majority of the cells before enrichments. When adding the limiting factor, bacteria recovered stoichiometric equilibrium and/or energy capacity which gave them the capacity to assimilate leucine again. Such unbalanced growth is often the explanation for the strong changes generally observed with the thymidine or the leucine technique, compared to that of abundances (Carlson and Ducklow, 1996). Thus the increase of leucine incorporation rate does not mean 
immediately a change in population. However, rapid growth of gamma-proteobacteria after FeN and "all" additions (Van Wambeke, unpub. results) was observed at the GYR site after $48 \mathrm{~h}$ of enrichments. A shift in bacterial population is generally an obligatory consequence of long term confinement and enrichments (Pinhassi et al., 2006). The number of heterotrophic flagellates increased, suggesting that bacterial predation was also enhanced after some stimulation of heterotrophic bacteria (GYR site, N enrichments, Table 4), and consequently regulated bacterial abundances. In conclusion, the leucine incorporation rates were thus better indicators than abundances for tracking factors limiting bacterial growth. Nevertheless, responses could have been different in terms of intensity or delay with other tracers of heterotrophic activity or using pre-filtered samples (Carlson and Ducklow, 1996; Donachie et al., 2001).

\subsection{Direct versus indirect limitation}

There has been much debate about direct (suppression of a real limiting factor) or indirect (stimulation of phytoplankton by the added component which induces a surplus of DOM production fuelling heterotrophic bacteria) effects of iron and other macronutrients limitation on heterotrophic bacteria (Table 5).

The timing and magnitude of responses of phytoplanktonic parameters (primary production, chlorophyll biomass) compared to that of heterotrophic bacteria in the experiment performed under TMC have helped to argue for possible direct or indirect effect of nutrient additions. If iron alone induced a positive stimulation of leucine activity within the Marquesas plateau (MAR site), addition of other nutrients $\mathrm{N}+\mathrm{P}+\mathrm{Si}$ ("all") without $\mathrm{Fe}$ stimulated leucine activity at the same level (factor 2 compared to the control at the same time, Fig. 2). In addition, chlorophyll biomass increased compared to the control, by a factor equivalent to that of leucine activity in $24 \mathrm{~h}$, and even more after $48 \mathrm{~h}$ (factor 3, Table 4). It is thus probable that the effect of Fe on leucine activity was indirect. The major effect obtained at the MAR site is however obtained in the non-amended control $(\times 20$ at the MAR site in the "trace metal clean" conditions, Fig. 2), although chlorophyll biomass increased only by $\times 1.5$ in this control (Table 4). It is possible that sufficient amounts of labile DOC were present, allowing a rapid bacterial growth without any enrichment, which implies that heterotrophic bacteria were not limited at all after a $24 \mathrm{~h}$ confinement at the MAR site. The capacity of bacteria to grow on bulk DOC was also seen in the vicinity of MAR site, up to $125^{\circ} \mathrm{W}$, as a strong growth in the non-amended controls was observed up to station STB5 (Fig. 4a). Interpretation of growth in a non-amended control is difficult because the use of batch experiments last for a few days. This implies to take into account bottle effect: underestimation of the levels of the trophic web, and possible destruction of fragile cells during handling that fuels labile organic resources for heterotrophic

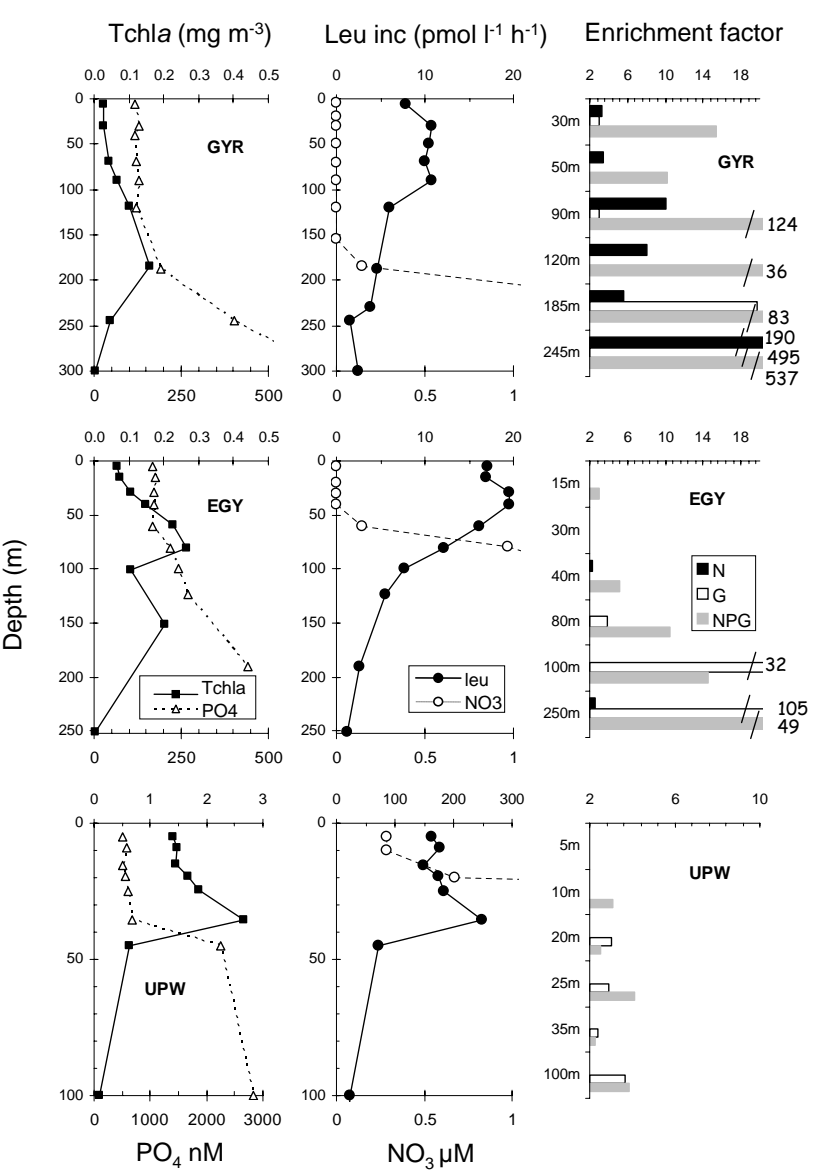

Fig. 5. Distribution of in situ chlorophyll a, leucine incorporation rates, nitrate and phosphate concentrations along vertical profiles, at sites GYR, EGY and UPW and responses to bioassays. Bioassays are expressed in terms of stimulation factor after N, G and NPG additions (leucine activity divided by leucine activity in the control at the same time). Only stimulation factors greater than 2 were plotted.

bacteria. However, all the other experiments have been performed in the same conditions, and the non-amended control did not increase that much. Possible other explanations are the change in the top-down control of bacteria or non steady state of bacterial growth at the time of the sampling at these stations. Day-to-day changes in in situ primary production, as well as in situ specific leucine incorporation rates have been observed during occupation of the MAR site (Van Wambeke et al., 2008a) and argue for this second hypothesis.

At the GYR site, the addition of iron did not result in any significant increase of photosynthesis rates (Table 4). Although dissolved iron was low and constant along most of the transect $(\sim 0.1 \mathrm{nM}$ in surface), it was shown that phytoplankton was acclimated to iron deprivation in the centre of the gyre (Bonnet el al., 2008). N addition alone (nitrate+ammonium) or in combinations (FeN, "all") have all stimulated chlorophyll and primary production ( 24 and $48 \mathrm{~h}$ ). 
Table 5. Review of factors enhancing some bacterial variables among different oceanic environments (Leu, Tdr: production based on Leucine and Thymidine technique, BN: bacterial numbers, BS: bacterial size, EEA: ectoenzymatic activities, $\mathrm{O}_{2}$ : respiration, BGE: bacterial growth efficiencies, DIV: diversity). DCM deep chlorophyll maximum, PE-DOM : filtrate of heat killed plankton extract ( $>335 \mu \mathrm{m}), \mathrm{Me}+\mathrm{Vit}:$ trace metals+vitamins, glu: glucose, DFAA: dissolved free amino acids, $\mathrm{NH}_{4}$ : ammonium, $\mathrm{NO}_{3}$ : nitrate, Fe: iron. Co refers to colimitation. ${ }^{*}$ in situ fertilization experiments. When carbon is limiting, and when the information was available, the terms in italic (resource, not clear and energy) refer to the authors' conclusions about energy versus resource limitation.

\begin{tabular}{|c|c|c|c|c|c|c|}
\hline area & date & parameter followed & nutrients tested & limitation by & $\begin{array}{l}\text { effect direct } \\
\text { vs. cascade }\end{array}$ & \\
\hline Gulf of Mexico to Mississippi. river plume & Jan June 1993 & Leu, BN, $\mathrm{O}_{2}$ & $\mathrm{NH}_{4}, \mathrm{PO}_{4}, \mathrm{Me},+\mathrm{Vit}$, glu & $\mathrm{P}$ & & Pomeroy et al., 1995 \\
\hline Sargasso Sea off Bermuda & Jul oct 92, Mar Jul 93, Jan 94 & Leu, Tdr, BN, BS & $\mathrm{NH}_{4}, \mathrm{PO}_{4}$, glu, DFAA, algal lysate & $\mathrm{C}$ (resource) & & Carlson and Ducklow, 1996 \\
\hline Med Sea, Western, Ionian, Levantine & June and Sept 99 & Leu & $\mathrm{NO}_{3}, \mathrm{PO}_{4}$, glu & co C-P, P & & Van Wambeke et al., 2002 \\
\hline $\begin{array}{l}\text { Med Sea, Catalano-Balearic Basin, surface } \\
\text {, DCM }\end{array}$ & Jun 95, Jun Sept 96 & Leu, BN & $\mathrm{NO}_{3}, \mathrm{PO}_{4}$, glu & $\begin{array}{l}\mathrm{P}, \text { co C-P } \\
\mathrm{C}, \mathrm{N}\end{array}$ & & Sala et al., 2002 \\
\hline Med Sea, Ionian, Cretan, Levantine Basins & Jan Feb 1995 & $\mathrm{Tdr}, \mathrm{BN}$ & $\mathrm{PO}_{4}, \mathrm{NH}_{4}, \mathrm{Fe}, \mathrm{EDTA}$ & $\mathrm{P}$ & & Zohary and Robarts, 1998 \\
\hline Med Sea, Levantine (Cypprus Gyre) & & Leu, BN & $\mathrm{PO}_{4}^{*}$ & $\mathrm{P}$ & direct & Thingstad et al., 2005 \\
\hline Subarctic Pacific, gulf of Alaska & Sept 1987, May Aug 1988 & Tdr, Leu, BN & $\mathrm{NH}_{4}^{4}$, DFAA, glu, protein, alkylamines & $\mathrm{C}$ (energy) & & Kirchman, 1990 \\
\hline Subtropical North Pacific, St ALOHA & Dec 96-Apr 98 & glucose uptake, EEA & $\mathrm{NH}_{4}, \mathrm{NO}_{3}$, leu, his, glu & co N-C (not clear) & & Donachie et al., 2001 \\
\hline Eastern North Pacific, California current & June Oct 1992 & $\mathrm{O}_{2}, \mathrm{BN}, \mathrm{BGE}$ & PE-DOM, glu, $\mathrm{NH}_{4}$, urea, $\mathrm{PO} 4$, DFAA & $\mathrm{C}$ (energy) & & Cherrier et al., 1996 \\
\hline Eastern North Pacific, California current & June 96, June 97 & Leu, BN & $\mathrm{Fe}$ & & not clear & Hutchins et al., 1998 \\
\hline Eastern Equatorial Pacific, IRONEX II & May 1995 & Leu, BN & $\mathrm{Fe}^{*}$ & $\mathrm{Fe}$ & not clear & Cochlan, 2001 \\
\hline South East Pacific, Tuamotu atolls & Nov 95, Mar 96 & Tdr & $\mathrm{NH}_{4}, \mathrm{PO}_{4}$, glu & $\mathrm{N}, \mathrm{C}, \mathrm{P}$, co C-N & & Torréton et al., 2000 \\
\hline Ocean around atolls & & & & C & direct & \\
\hline South Eastern Pacific Gyre (this study) & Nov-Dec 2005 & Leu, BN & $\mathrm{Fe}, \mathrm{NH}_{4}+\mathrm{NO}_{3}, \mathrm{PO}_{4}$, glu & $\mathrm{N}$ & direct & This study \\
\hline Antarctic, Gerlashe Strait & October 1995 & & $\mathrm{Fe}$ & $\mathrm{Fe}$ & direct & Palkulski et al., 1996 \\
\hline Southern Ocean, Atlantic sector & austral summer $97 / 98$ & Leu, BN & $\mathrm{NH}_{4} \mathrm{PO}_{4}$ glu & $\mathrm{C}$ & & Tortell et al., 1996 \\
\hline Southern Ocean, Atlantic sector, EISENEX & Nov 2000 & Leu, Tdr, BN, EEA, DIV & $\mathrm{Fe}^{*}$ & $\mathrm{Fe}$ & not clear & Arrieta et al., 2004 \\
\hline
\end{tabular}

The leucine incorporation rate in the GYR site is statistically higher in $\mathrm{N}$ and $\mathrm{G}$ enriched sample than in the control $(\times 4.6$ and $\times 3$ enrichment factor at $24 \mathrm{~h}, \times 8.9$ and $\times 3.5$ at $48 \mathrm{~h}$, respectively, $p<0.05$, Table 4 ). The growth after $\mathrm{N}$ addition is not higher than that after $\mathrm{G}$ addition at $24 \mathrm{~h}$, but it is at $48 \mathrm{~h}(p<0.05)$. Thus, based on a $48 \mathrm{~h}$ response, it seems that $\mathrm{N}$ addition provides better possibility to grow to heterotrophic bacteria than addition of glucose alone. This trend is confirmed from non TMC experiments made along different stations inside the gyre (STB6-STB15). In these experiments, the increase of leucine incorporation rates after glucose addition is lower that that obtained after $\mathrm{N}$ addition (Wilcoxon signed-rank test, $p=0.038, n=9$ pairs of comparison, box plots Fig. 4b). These results suggests that the limitation by $\mathrm{N}$ of bacterial production within the gyre is direct.

But other observations suggest that labile carbon acts sequentially as a second limiting factor. Indeed, within the surface waters of stations STB6-STB15, addition of glucose alone did not stimulate leucine incorporation rates (Wilcoxon signed-rank test between $\mathrm{C}$ and $\mathrm{G}$ enriched samples, $n=9$ pairs of comparison, $p=0.07$ ), but addition of $\mathrm{N}$ alone did (comparison $\mathrm{C}-\mathrm{N}, p<0.01$ ). However, leucine incorporation rates increased statistically much more in NPG amended samples than in $\mathrm{N}$ amended samples (Fig. 4, median of increasing factor switched from $\times 4.2$ to $\times 37$, Wilcoxon signed-rank test between N and NPG enriched samples, $n=9$ pairs of comparison, $p<0.01$ ). Considering further that $\mathrm{P}$ never stimulated bacteria, we infer that in the area between $122^{\circ} \mathrm{W}$ and $95^{\circ} \mathrm{W}$, labile organic carbon rapidly becomes a limiting factor after $\mathrm{N}$ addition.

Within the deep chlorophyll maximum (DCM), however, glucose is the first limiting nutrient, not $\mathrm{N}$ (Fig. 5). A similar switch from a mineral nutrient within surface layer to organic
C limitation within DCM has been evidenced in the Mediterranean Sea (Sala et al., 2002; Van Wambeke et al., 2002).

The rapidity of the response of heterotrophs versus autotrophs after relieving the $\mathrm{N}$ limiting nutrient in the South Pacific gyre could have consequences on the metabolic balance of this environment. Recently, it has been shown that $5-10 \%$ of deep sea water mixed with water from the nutrientlimited mixed layer of the North Pacific Gyre provided a set of nutrient enrichment sufficient to significantly enhance the net community production after 5 days (Mc Andrew et al., 2007). Thus, the question arises here if, in our nitrogen enrichment experiments made at the GYR site, photosynthesis was also notably favoured compared to respiration. Oxygen budgets were not measured in our experiments, but as our stimulation factors were much greater with leucine incorporation rates than particulate primary production, our results would suggest the opposite (i.e. enrichment would favour net heterotrophy at the GYR site). Nevertheless, the leucine incorporation rate is not respiration, and possible changes in leucine conversion factors, as well as in bacterial growth efficiencies with time could not be ruled out. Indeed, the relieving of a factor limiting heterotrophic bacteria enhances bacterial growth efficiency (Carlson and Ducklow, 1996). Also, our experiments lasted only $48 \mathrm{~h}$, whereas significant chlorophyll biomass and net community production occurred only after 4-5 days in the Mc Andrew et al. (2007) experiments. Finally, the rates at which autotrophic and heterotrophic cells developed in our experiment might have been influenced by enzymatic properties of uptake systems for ammonium and nitrate which differs inside these two groups, heterotrophic bacteria being favoured by ammonium addition, whereas only nitrate were provided by deep sea water enrichments in Mc Andrew et al. (2007) approach. 
4.3 Carbon versus energy limitation of heterotrophic bacteria

Because the organic molecule tested is also often an energyrich molecule easily entering catabolic pathways (e.g. glucose), one could wonder if this carbon source is tracking carbon resource limitation or energy limitation (Table 4). Free glucose (not combined) is rare in this area (Sempéré et al., 2008), suggesting that this molecule plays an important role in energy restoration once added. DOC is probably highly refractory, due to strong UV radiation effects (Tedetti et al., 2007). Indeed, it has been shown that growth of heterotrophic bacteria at the GYR site after a one day UV exposure of DOM is partly inhibited (Sempéré et al., 2008). It is probable that the limitation in $\mathrm{N}$ and energy prevents the synthesis of enzymes able to degrade the bulk accumulated DOC present in this area $(118 \mu \mathrm{M}$ at GYR, Table 1, Raimbault et al., 2008). Indeed, in addition to changes in populations (Pinhassi et al., 2006), induction of some genes after the relieving of some limiting nutrients has been observed (Arietta et al., 2004). Bacteria were described as energy limited in the South Pacific (Kirchman, 1990), and in the Eastern North Pacific (Cherrier et al., 1996), but resource limited in the Sargasso Sea (Carlson and Ducklow, 1996). In addition, conflicting interpretation are sometimes given to the same observation, for instance when comparing enhancement of bacterial activity after amino acids addition or with glucose+ammonium addition (Kirchman, 1990; Carlson and Ducklow, 1996; Donachie et al., 2001). It is probably impossible to dissociate notions of energy versus resource limitation in nature and varying conclusions given probably rely on the quality of organic matter present and the parameter tracking heterotrophic activity.

In the centre of the South Pacific Gyre, nitrogen was a common primarily factor limiting phytoplankton and bacteria. Competitive advantages for $\mathrm{N}$ between bacteria and phytoplankton might thus exist and vary with irradiance levels, which had not been considered in this study. Indeed, it has also been suggested that the factors limiting bacteria could change at a daily scale (Shiah, 1999; Kuipers et al., 2000). DOC produced by phytoplankton release could be a major source of carbon and energy for bacteria. The huge needs of nitrogen and energy source for heterotrophic bacteria, as well as their strong plasticity to grow again once limitation is relieved, are probably the key factors explaining the strong coupling between phytoplankton and bacteria as seen on diel cycles (Van Wambeke et al., 2008b).

\section{Conclusions}

A large set of enrichment experiments was performed here along a $8000 \mathrm{~km}$ transect, sometimes along vertical profiles, allowing a broad generalization of the observed trends over a large spatial scale of the South Pacific Ocean in an aus- tral summer situation. Our enrichment experiments have shown that iron was never the single nutrient limiting bacterial production. From the vicinity of the Marquesas Islands to approx $125^{\circ} \mathrm{W}$, the high response in the control suggests no limitation. Nitrogen was the first factor limiting heterotrophic bacterioplankton within the surface layers in the centre of the south Pacific Gyre, with labile carbon acting sequentially as a second limiting factor. Overall the surface layers around the eastern border of the South Pacific Gyre $\left(91^{\circ} \mathrm{W}\right.$ to the upwelling off Chile), labile carbon was the primarily factor limiting heterotrophic bacterial production.

Because the weak horizontal advection in the centre of the South Pacific Gyre and because intense seasonal convective mixing is excluded (Raimbault et al., 2008), this suggests that the situation of nitrogen limitation could be permanent throughout the entire year. However, nitrogen was a common primarily factor limiting both phytoplankton and bacteria, which probably had consequences on their relationships at short time scales. The heterotrophic bacterioplankton of the South Pacific Gyre lives in a very dynamic situation which is difficult to determine adequately, and current methods and tools for detecting limiting factors on short incubation time are urgently needed.

Acknowledgements. This work was supported by French program PROOF (Processus biologiques dans l'océan et flux), Centre National de la Recherche Scientifique (CNRS). This is a contribution of the BIOSOPE project of the LEFE-CYBER program. We also thank Stéphane Blain and Flavienne Bruyant for help in sample processing of trace metal clean experiments, Carolina Grob for collecting bacterial abundance samples on board, Hervé Claustre for leadership of this program, and 2 anonymous reviewers who helped to improve this ms.

Edited by: M. Dai

\section{References}

Arrieta, J., Weinbauer, M., Lute, C., and Herndl, G.: Response of bacterioplankton to iron fertilization in the southern Ocean, Limnol. Oceanogr., 49, 799-808, 2004.

Blain, S., Bonnet, S., and Guieu, C.: Dissolved iron distribution in the tropical and sub tropical South Eastern Pacific, Biogeosciences, 5, 269-280, 2008, http://www.biogeosciences.net/5/269/2008/.

Bonnet, S., Guieu, C., Bruyant, F., Prášil, O., Van Wambeke, F., Raimbault, P., Moutin, T., Grob, C., Gorbunov, M., Zehr, J. P., Masquelier, S., Garczarek, L., and Claustre, H.: Nutrient limitation of primary productivity in the Southeast Pacific (BIOSOPE cruise), Biogeosciences, 5, 215-2225, 2008, http://www.biogeosciences.net/5/215/2008/.

Bruland, K. W., Franks, R. P., Knauer, G. A. and Martin, J. H: Sampling and analytical methods for the determination of $\mathrm{Cu}, \mathrm{Cd} . \mathrm{Zn}$, and $\mathrm{Ni}$ at the nanogram per liter level in sea water, Anal. Chim. Acta, 105, 234-245, 1979. 
Carlson, C. A. and Ducklow, H. W.: Growth of bacterioplankton and consumption of dissolved organic carbon in the Sargasso Sea, Aquat. Microb. Ecol., 10, 69-85, 1996.

Cherrier, J., Bauer, J. E., and Druffel, E. R. M.: Utilization and turnover of labile dissolved organic matter by bacterial heterotrophs in eastern North Pacific surface waters, Mar. Ecol. Prog. Ser., 139, 267-279, 1996.

Church, M., Hutchins, D., and Ducklow, H. W.: Limitation of bacterial growth by dissolved organic matter and iron in the Southern Ocean, Appl. Environ. Microbiol., 66, 455-466, 2000.

Claustre, H., Sciandra, A., and Vaulot, D.: Introduction to the special section Bio-optical and biogeochemical conditions in the South East Pacific in late 2004: the BIOSOPE program, Biogeosciences, 5, 679-691, 2008,

http://www.biogeosciences.net/5/679/2008/.

Cochlan, W. P.: The heterotrophic bacterial response during a mesoscale iron enrichment experiment (IronEx II) in the Eastern equatorial Pacific Ocean, Limnol. Oceanogr., 46, 428-435, 2001.

Cotner, J., Ammermann, J., Peele, E., and Bentzen, E.: Phosphoruslimited bacterioplankton growth in the Sargasso Sea, Aquat. Microb. Ecol., 13, 141-149, 1997.

Duhamel, S., Moutin, T., Van Wambeke, F., Van Mooy, B., Rimmelin, P., Raimbault, P., and Claustre, H.: Growth and specific Puptake rates of bacterial and phytoplanktonic communities in the Southeast Pacific (BIOSOPE cruise), Biogeosciences, 4, 941956, 2007, http://www.biogeosciences.net/4/941/2007/.

Donachie, S. P., Christian, J. R., and Karl, D. M.: Nutrient regulation of bacterial production and ectoenzyme activities in the subtropical North Pacific Ocean, Deep-Sea Res. II, 48, 1719-1732, 2001.

Granéli, W., Carlsson, P., and Bertilsson, S.: Bacterial abundance, production and organic carbon limitation in the Southern Ocean (39-62 $\left.{ }^{\circ} \mathrm{S}, 4-14^{\circ} \mathrm{E}\right)$ during the austral summer 1997/1998, Deep-Sea Res. II, 51, 2569-2582, 2004.

Grob, C., Ulloa, O., Claustre, H., Huot, Y., Alarcón, G., and Marie, D.: Contribution of picoplankton to the total particulate organic carbon concentration in the eastern South Pacific, Biogeosciences, 4, 837-852, 2007, http://www.biogeosciences.net/4/837/2007/.

Hutchins, D. A., DiTullio, G. R., Zhang, Y., and Bruland, K. W.: An Iron limitation mosaic in the California upwelling regime, Limnol. Oceanogr., 43, 1037-1054, 1998.

Kirchman, D. L.: The uptake of inorganic nutrients by heterotrophic bacteria, Microb. Ecol., 28, 255-271, 1994.

Kirchman, D. L.: Limitation of bacterial growth by dissolved organic matter in the subarctic Pacific, Mar. Ecol. Prog. Ser., 62, 47-54, 1990.

Kirchman, D. L. and Rich, J.: Regulation of bacterial growth rates by dissolved organic carbon and temperature in the Equatorial Pacific Ocean, Microb. Ecol., 33, 11-20, 1997.

Kirchman, D. L., Meon, M., Cottrell, M. T., Hutchins, D. A., Weeks, D., and Bruland, K. W.: Carbon versus iron limitation of bacterial growth in the California upwelling regime, Limnol. Oceanogr., 45, 1681-1688, 2000.

Kirchman, D. L., Elifantz, H., Dittel, A., Malmstrom, R., and Cottrell, M.: Standing stocks and activity of Archaea and Bacteria in the western Arctic Ocean, Limnol. Oceanogr., 52, 495-507,
2007.

Kuipers, B.: Diel periodicity of bacterioplankton in the euphotic zone of the subtropical Atlantic Ocean, Mar. Ecol. Prog. Ser., 201, 13-25, 2000.

McAndrew, P., Bjorkman, K., Church, M., Morris, P., Jachowski, N., Williams, P. J. le. B., and Karl, D.: Metabolic response of oligotrophic plankton communities to deep water nutrient enrichment, Mar. Ecol. Prog. Ser., 332, 63-75, 2007.

Moutin, T., Karl, D. M., Duhamel, S., Rimmelin, P., Raimbault, P., Van Mooy, B. A. S., and Claustre, H.: Phosphate availability and the ultimate control of new nitrogen input by nitrogen fixation in the tropical Pacific Ocean, Biogeosciences, 5, 95-109, 2008, http://www.biogeosciences.net/5/95/2008/.

Obernosterer, I., Catala, P., Lami, R., Caparros, J., Ras, J., Bricaud, A., Dupuy, C., Van Wambeke, F. and Lebaron, P.: Biochemical characteristics and bacterial community structure of the sea surface microlayer in the South Pacific Ocean, Biogeosciences, 5: 693-705, 2008a.

Obernosterer, I., Christaki, U., Lefèvre, D., Catala, P., Van Wambeke, F., and Lebaron, P.: Rapid bacterial mineralization of organic carbon produced during a phytoplankton bloom induced by natural iron fertilization in the Southern Ocean, DeepSea Res. II, 55, 777-789, 2008b.

Olivier, J. L., Barber, R. T., Smith, W. O., and Ducklow, H. W.: The heterotrophic bacterial response during the southern Ocean Iron Experiment (SOFeX), Limnol. Oceanogr., 49, 2129-2140, 2004.

Pakulski, J. D., Coffin, R. B., Kelley, C. A., Holder, S. L., Downer, R., Aas, P., Lyons, M. M., and Jeffrey, W. H.: Iron stimulation of Antarctic bacteria. Nature, 383, 133-134, 1996.

Pinhassi, J., Gómez-Consarnau, L., Alonso-Sáez, L., Sala, M., Vidal, M., Pedrós-Alió, C., and Gasol, J.: Seasonal changes in bacterioplankton nutrient limitation and their effects on bacterial community composition in the NW Mediterranean Sea, Aquat. Microb. Ecol., 44, 241-252, 2006.

Pomeroy, L. R., Sheldon, J. E., Sheldon, W. M., and Peters, F.: Limits to growth and respiration of bacterioplankton in the Gulf of Mexico, Mar. Ecol. Prog. Ser., 117, 259-268, 1995.

Raimbault, P., Garcia, N.: Evidence for efficient regenerated production and dinitrogen fixation in nitrogen-deficient waters of the South Pacific Ocean: impact on new and export production estimates, Biogeosciences, 5, 323-338, 2008

Raimbault, P., Garcia, N., and Cerutti, F.: Distribution of inorganic and organic nutrients in the South Pacific Ocean - Evidence for long-term accumulation of organic matter in nitrogen-depleted waters, Biogeosciences, 5, 281-298, 2008, http://www.biogeosciences.net/5/281/2008/.

Ras, J., Claustre, H., and Uitz. J.: Spatial variability of phytoplankton pigment distributions in the Subtropical South Pacific Ocean: comparison between in situ and predicted data, Biogeosciences, 5, 353-369, 2008, http://www.biogeosciences.net/5/353/2008/.

Sala, M. M., Peters, F., Gasol, J. M., Pedrós-Alió, C., Marrassé, C., and Vaqué, D.: Seasonal and spatial variations in the nutrient limitation of bacterioplankton growth in the northwestern Mediterranean, Aquat. Microb. Ecol., 27, 47-56, 2002.

Shiah, F. K.: Diel cycles of heterotrophic bacterioplankton abundance and production in the ocean surface waters, Aquat. Microb. Ecol., 17, 239-246, 1999.

Sempéré, S., Tedetti, M., Charrière, B., Panagiotopoulos, C. and 
Van Wambeke, F.: Molecular distribution and bacterial availability of dissolved sugars in the south East Pacific, Biogeosciences Discuss., 5, 725-750, 2008, http://www.biogeosciences-discuss.net/5/725/2008/.

Tedetti, M., Sempéré, R., Vasilkov, A., Charrière, B., Nérini, D., Miller, W. L., Kawamura, K., and Raimbault, P.: High penetration of ultraviolet radiation in the south east Pacific waters, Geophys. Res. Lett., 34, L12610, doi:10.1029/2007GL029823, 2007.

Thingstad, T.: Control of bacterial growth in idealized food webs, in: Microbial Ecology of the Oceans, edited by: Kirchman, D. L., Wiley-Liss, New York, 239-260, 2000.

Thingstad, T., Krom, M., Mantoura, F., Flaten, G., Groom, S., Herut, B., Kress, N., Law, C., Pasternak, A., Pitta, P., Psarra, S., Rassoulzadegan, F., Tanaka, T., Tselepides, A., Wassmann, P., Woodward, M., Riser, C., Zodiatis, G., and Zohary, T.: Nature of phosphorus limitation in the ultraoligotrophic eastern Mediterranean, Science, 309, 1068-1071, 2005.

Tortell, P. D., Maldonaldo, M. T., Granger, J., and Price, N. M.: Marine bacteria and biogeochemical cycling of iron in the oceans, FEMS Microb. Ecol., 29, 1-11, 1999.

Tortell, P. D., Maldonado, M. T., and Price, N. M.: The role of heterotrophic bacteria in iron-limited ecosystems. Nature, 383, 330-332, 1996.
Torréton, J.-P., Talbot, V., and Garcia, N.: Nutrient stimulation of bacterioplankton growth in Tuamotu atoll lagoons, Aquat. Microb. Ecol., 21, 125-137, 2000.

Van Wambeke, F., Christaki, U., Giannakourou, A., Moutin, T., and Souvemerzoglou, K.: Longitudinal and vertical trends of bacterial limitation by phosphorus and carbon in the Mediterranean Sea, Microb. Ecol., 43, 119-133, 2002.

Van Wambeke, F., Obernosterer, I., Moutin, T., Duhamel, S., Ulloa, O., and Claustre, H.: Heterotrophic bacterial production in the South East Pacific: Longitudinal trends and coupling with primary production, Biogeosciences, 5, 157-169, 2008a, http://www.biogeosciences.net/5/157/2008/.

Van Wambeke, F., Tedetti, M., Duhamel, S., and Sempéré, R.: Diel variability of heterotrophic bacterial production and UV doses in the South East Pacific, Biogeosciences Discuss., 5, 435-462, 2008b, http://www.biogeosciences-discuss.net/5/435/2008/.

Zohary, T., and Robarts, R. D.: Experimental study of microbial P limitation in the eastern Mediterranean, Limnol. Oceanogr., 43, 387-395, 1998. 